Association for Information Systems AIS Electronic Library (AISeL)

AMCIS 2004 Proceedings

Americas Conference on Information Systems

(AMCIS)

December 2004

\title{
Do Concerns about Error in Data and Access to DataAffect Students' Feeling of Alienation?
}

Joseph Mollick

Southern Illinois University at Carbondale

Follow this and additional works at: http://aisel.aisnet.org/amcis2004

\section{Recommended Citation}

Mollick, Joseph, "Do Concerns about Error in Data and Access to DataAffect Students' Feeling of Alienation?" (2004). AMCIS 2004

Proceedings. 562.

http://aisel.aisnet.org/amcis2004/562

This material is brought to you by the Americas Conference on Information Systems (AMCIS) at AIS Electronic Library (AISeL). It has been accepted for inclusion in AMCIS 2004 Proceedings by an authorized administrator of AIS Electronic Library (AISeL). For more information, please contact elibrary@aisnet.org. 


\title{
Do Concerns about Error in Data and Access to Data Affect Students' Feeling of Alienation?
}

\author{
Joseph S. Mollick \\ Southern Illinois University at Carbondale \\ jsmollic@siu.edu
}

\begin{abstract}
Organizations such as universities collect and use personal data about customers such as students. How do students feel about their university's practices related to error in data and access to personal data? Using data collected via a survey of 187 students at a large U.S. university, we investigate the effects of these two privacy and security concerns on students' feeling of alienation. Implications of the results are discussed in light of ethics, strategy, design, control and administration of personal information management systems.
\end{abstract}

\section{KEYWORDS}

Privacy, Alienation, Error, Access to Data, Information Management, Universities, Students.

\section{INTRODUCTION}

As computerized information management systems (IMS) continue to shape modern organizations, ethical tensions between organizations and individuals affected by organizational practices related to the management of privacy and security of data gain heightened importance. Concerns about access to data and error in data, have been identified as two of the four concerns individuals have about personal information privacy (Smith et al., 1996). As organizations become more information-based (Drucker, 1988), ethical concerns related to individual's information privacy and security become more relevant, creating an urgency to study the antecedents and consequences of individuals' information privacy concerns (IIPC). A significant amount of literature exists about the antecedents of IIPC, and about legal, social, and organizational responses to it. On the basis of Culnan (1993) and Smith et al (1996), IIPC has been defined in this paper as an individuals' level of discomfort, fear of harm, and feeling of loss of control associated with organizational practices related to management of access to data and error in personal data stored in databases and used in operations of organizations such as universities. Such negative beliefs may result in alienation, a feeling of separation (Allison, 1978) from the university environment and the self. The research question we ask is: do IIPC affect students' feeling of alienation at US universities? There are at least two reasons that make this question timely and relevant. First, students at US universities who come from all over the world are subjected to practices of personal data collection and use. Second, recent legislation such as the Patriot Act has relevant implications for information exchange relationships between organizations and individuals (Rackow, 2002). The question asked in this study is timely and can be relevant to management of access to data (X2) and error (X1) in data collected, stored and used by organizations that are populated by both Americans and citizens from different nationalities, cultures and religions.

\section{PRIOR STUDIES ON EFFECTS OF IIPC}

To understand the effects of IIPC in this study, it is necessary to briefly review prior studies. IIPC has been studied in different technological, organizational and other contexts. Technological contexts include 'yellow journalism' in newspapers (Warren \& Brandeis, 1890) and the mass media , databases (Date, 1986; Garfinkel, 2000; Cespedes \& Smith, 1993), computer networks (Rotenberg, 1993), the Internet and related technologies such as e-mail (Kent, 1993), software cookies (Berghel, 2001), e-commerce systems and Internet marketing (Wang et al, 1998). Organizational contexts include the U.S. government and its different agencies that create the impression that the U.S. is a database nation (Garfinkel, 2000); different industries in the private sector such as health care (Rindfleisch, 1997) and insurance (Studdert, 1999; Borna \& Avila, 1999); data flows in law enforcement and criminal justice systems (Laudon, 1986), as well as educational institutions such as schools (Hancock, 2001) and universities (Sethna \& Barnes, 1999).

However, few studies have attempted to build theories and test hypothesized relationships among the different dimensions of IIPC and their effects on specific outcome variables. Examples of outcome variables or consequences of IIPC that have been theorized and empirically tested indicate that organizational information management practices, individuals' ethical perceptions of these practices, and societal responses are inextricably linked (Culnan, 1993; Milberg et al, 1995; Smith, 1994, 
and Stone et al., 1983). It has been found that privacy concerns affect an individual's willingness to give personal data to traditional organizations (Culnan et al., 1999) as well as to web-based vendors (Panichpathom, 2000;). Culnan (1993) found that IIPC was a viable cause of negative public attitude toward organizations engaged in privacy-invasive marketing practices. Milberg et al (1995 \& 2000) found that privacy concerns led people to support governmental intervention over industry self-regulation. Vance (2000) found that privacy concern led employment seekers to evaluate some organizations more positively than others as a work environment. In another related study, Westin (1979) studied an individual's attitude toward information privacy in the U. S. and found evidence of individual's feeling of alienation from society and government in general that could be attributed to privacy-threatening data management practices.

To show continuity of the current study with prior studies, the constructs used in this study, their definitions and sources are summarized in Table 1a.

\begin{tabular}{|c|l|l|l|}
\hline$\underline{\text { Symbol }}$ & Construct & Definition & References \\
\hline $\mathbf{X}_{\mathbf{1}}$ & $\begin{array}{l}\text { Concern } \\
\text { About } \\
\text { Errors }\end{array}$ & $\begin{array}{l}\text { "Concern that protections against } \\
\text { deliberate and accidental errors in } \\
\text { personal data are inadequate." (Smith et } \\
\text { al., 1996) }\end{array}$ & $\begin{array}{l}\text { Date, 1986 } \\
\text { HEW, 1973 } \\
\text { Laudon, 1986 } \\
\text { Mason, 1986 } \\
\text { Mason et al, 1995 } \\
\text { Miller, 1982 }\end{array}$ \\
\hline $\mathbf{X}_{\mathbf{2}}$ & $\begin{array}{l}\text { Concern } \\
\text { about } \\
\text { improper } \\
\text { access } \\
\text { data }\end{array}$ & $\begin{array}{l}\text { "Improper Access Concern that data } \\
\text { about individuals are readily available to } \\
\text { people not properly authorized to view } \\
\text { or work with this data." (Smith et al., } \\
\text { 1996) }\end{array}$ & $\begin{array}{l}\text { Date, 1986 } \\
\text { Linowes, 1989 } \\
\text { PPSC, 1977 }\end{array}$ \\
\hline $\mathbf{Y}$ & $\begin{array}{l}\text { Alienation } \\
\text { The degree to which a consumer has }\end{array}$ \\
& $\begin{array}{l}\text { negative beliefs and feels neglected by } \\
\text { universities in general with respect to } \\
\text { personal information management } \\
\text { practices. }\end{array}$ & $\begin{array}{l}\text { Allison, 1978 } \\
\text { Singh, 1988; 1990 } \\
\text { Singh and Wilkes, 1996 }\end{array}$ \\
\hline
\end{tabular}

Table 1a: Summary of Constructs and their Sources

\section{THE RESEARCH MODEL}

A large U.S. university represents what Peter Drucker (1988) would call an 'information-based' organization, and students would represent customers of that information-based organization. As presented in the research model in Figure 1, we attempt to theorize and empirically test the effects of two independent variables - students' concern about error in data $\left(\mathrm{X}_{1}\right)$, and concern about improper access to data $\left(\mathrm{X}_{2}\right)_{\text {— }}$ on students' feeling of being alienated by universities' practices related to personal data management (Y).

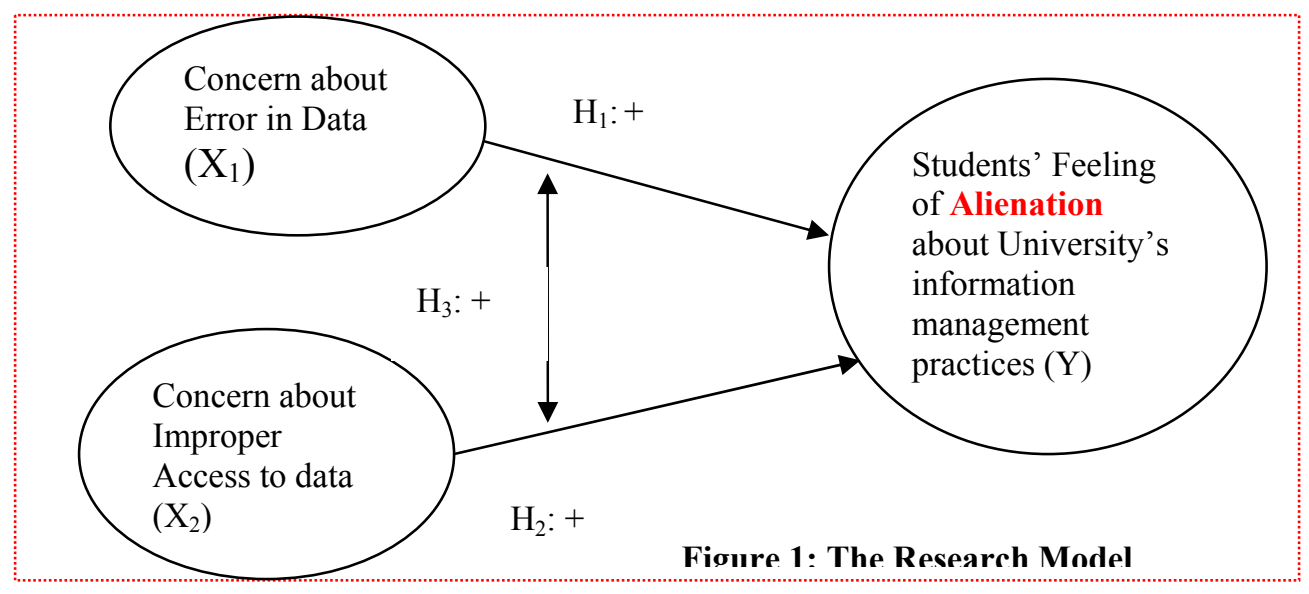




\section{Organization Theory and Alienation (Y)}

Students' feeling of alienation about their university can be viewed as a prototypical example of the relationship between an organization and customers who have been internalized (Thompson, 1967) by their organization. In the context of an existing relationship between an organization and its internalized customers, members have a sense of belonging (Barnard, 1938) and membership (Simon, 1976), and mutual dependency (Donaldson, 1975). Internalized customers who carry out their transactions with their organization in the context of a reciprocal relationship operate on the basis of an expectation of good faith that their organization will be ethical, trustworthy, procedurally fair and just in how it manages their personal information. Alienation can be viewed as a feeling that arises when the positive sense of belonging and membership turns sour or bitter and individuals perceive that their positive expectations are unfulfilled, ignored, neglected, violated or abused by their organization. Prior research indicates that individuals are more likely to perceive information collection procedures as privacy-invasive when the information is collected from someone who is not in the context of an existing relationship with the collecting organization (Stone \& Stone, 1990). As such, it is expected that students, when their university asks them for personal information, will not have high privacy concerns as non-students might have. For this reason, a relationship between students' privacy concerns and their feeling of alienation about their university's information management practices is expected to be mild. This is why the effect of students' privacy-concerns, $\mathrm{X}_{1}$ and $\mathrm{X}_{2}$, on their perception of alienation (Y) from the university is expected to be significant but mild unless there are exceptionally privacy-invasive practices at a university.

\section{Information-based Organizations}

We have chosen to study the effects of privacy concerns in the context of a relationship between students and their university because of the information-intensive nature of these individual-organization relationships. Peter Drucker (1988) predicted that organizations of the future would become increasingly information-based such as hospitals and universities. Organizations such as universities are expected to be conscience-carriers (Mason et al 1995, p.196) and moral agents (Mason et al., 1995; p.198-200) in how they use information-power (Mason et al., 1995; p.996) over different stakeholders (Freeman, 1984; Smith, 1994). Sources of power include information-based organizations' ability to collect, access, store, possess, legally own, control, share, communicate and buy or sell information about different stakeholders. Organizations are networks among individuals within and around an invisible legal entity. As such, different parties to the social network can be subjected to indignity, injustice and harm because of what information-based organizations do or fail to do with regard to ensuring the accuracy of customers' personal information and keeping in place management practices to protect customers from the harm that can befall them from improper access to data. The attitude that an affected party develops, such as a feeling of alienation, is not so much toward an individual employee of the organization, as toward the organization as a whole and the institution it represents because students might not know the exact point within the organizational hierarchy or processes where responsibility should be placed and where their feeling of alienation should be directed to.

\section{CONSTRUCTS AND HYPOTHESES}

\section{Organizational Ethics, Privacy and Security in Records Management and Alienation}

Customers evaluate organizational practices according to their ethical and moral concepts and form judgments as to whether a particular practice should be viewed as good for their well being or should be viewed as an expression of lack of professional care and ethical responsibility on the part of the organization. Ethical tensions in the domain of organizational information management systems develop from conflicts between the differing and, often, conflicting interests of an organization's owners, employees, customers, suppliers, partners, and governmental agencies. Our study focused on students' general concern about practices related to ensuring accuracy of data and controlling access to data stored in universities.

Mason (1986) identified four ethical issues related to management of information: property, access, privacy and accuracy. Smith et al (1996), through an extensive literature review and empirical testing and validation, identified four dimensions of individuals' privacy concern: concern about data collection, concern about data use, concern about access to data and concern about data error. Smith's study about information privacy concerns was related to organizations in general—not specifically about universities. Mollick and Pearson (2003) found evidence that two dimensions of privacy concernsconcern about data collection and concern about improper use of data contribute to students' feeling of alienation about information management systems at universities. The current study extends existing knowledge about individuals' information privacy concerns in that it theorizes and tests how the other two dimensions of individuals' information privacy 
concerns - concern about error in data $\left(\mathrm{X}_{1}\right)$ and concern about improper access to data $\left(\mathrm{X}_{2}\right)$--contribute to students' feeling of alienation $(\mathrm{Y})$ about information management systems at universities.

\section{The Dependent Variable (Y): Alienation}

Social thinkers such as Plato, Hegel, Marx, Weber and others have expressed concerns about one's relationship to the society in which one lives and to which one belongs. One such concern is that of alienation of an individual or a group by an organization, by an industry or by a larger society. Today's society is dominated by organizations and organizations are dominated by computerized information systems. Alienation is contextual and has been defined and measured differently under labels such as political alienation (Dean, 1960 \& 1961), social alienation (Nettler, 1975), and consumer alienation from the marketplace (Allison, 1978). Allison's instrument has been adapted to measure students' feeling of alienation from universities with regard to data privacy and security management practices. Alienation is a feeling of separation that involves sentiments of powerlessness, isolation and self-estrangement (Allison, 1978). It is important to study and understand customers' alienation because customers can respond to alienation in the form of poor performance or dropping out from school (Alvarez, 1990), legal or political activism, rebellion (Brookes, 2002), non-cooperation, or even violence (Friedland, 1999) against the organizational or social entity they hold responsible for their alienation.

Most prior studies dealing with customer's alienation focused on its sources and consequences but not in the context of customers' information privacy and security concerns. One exception is Westin's (1979) study that investigated customers' alienation resulting from privacy concerns. Westin (1979) found that U.S. citizens felt alienated by government's data collection practices because of their privacy concerns. It has been documented that customers whose complaints are ignored feel alienated (Lipton, 2000). In the context of privacy, an extended, generalized argument can be made that students whose privacy complaints and concerns are ignored will feel alienated. An organizational strategy of growth by merger and acquisition can be a source of alienation for customers (Hafner, 1988; Hemphill, 2000) because customers' privacy is lost and their risks of exposure and harm are increased. In the context of this study, an analogy can be made that information sharing among different branches or among different units of a large university or university system will be a privacy concern which may cause students to feel alienated. Caller ID technology, viewed as dehumanizing, has been identified as a source of alienation for telecom customers (Tanner, 1998). If organizational activities in the domain of data privacy and security management are perceived by students as unsatisfactory, unfriendly, risky, privacy-invasive and unsafe, the result can be that students will feel alienated.

\section{The Independent Variables}

\section{Concern about Error $\left(X_{1}\right)$}

Individuals' concern about error $\left(\mathrm{X}_{1}\right)$ in personal data collected, stored and used by organizations has been defined and measured in this study in light of one of the four dimensions of individuals' information privacy concern identified by Smith et al (1996) as quoted below:

"Many individuals believe that organizations are not taking enough steps to minimize problems from errors in personal data. Although some errors might be deliberate (e.g., a disgruntled employee maliciously falsifying data), most privacy-related concerns involve instead accidental errors in personal data. Early privacy studies detail some procedures for minimizing such errors (HEW, 1973; Westin and Baker, 1972; also see minor references in PPSC, 1977). Later works (Laudon, 1986; Linowes, 1989) document continuing problems in this domain.

Provisions for inspection and correction are often considered as antidotes for problems of erroneous data (HEW, 1973; PPSC, 1977; Smith, 1994). But many errors are stubborn ones, and they seem to snowball in spite of such provisions (Smith, 1994). In addition, a reluctance to delete old data--which can clearly become "erroneous" because of their static nature in a dynamic world--can exacerbate this problem (Miller, 1982). Also at issue are questions of responsibility in spotting errors: does a system rely on individuals to monitor their own files, or is there an overarching infrastructure in place (Bennett, 1992)? Although errors are sometimes assumed to be unavoidable problems in data handling, whether controls are or are not included in a system does represent a value choice on the part of the system's designers (Kling, 1978; Mowshowitz, 1976)." 


\section{Concern about Improper Access $\left(X_{2}\right)$}

Individuals' concern about improper access $\left(\mathrm{X}_{2}\right)$ to data has been identified as one of the four dimensions of individuals' concern about information privacy (Smith et al, 1996). It has also been identified by information security professionals as the most important dimension of information security (Ma \& Pearson, 2004). Mason (1986) identified improper access as one of the four ethical issues of information management. Thus, concern about access to data is shared by professionals and scholars in the domains of information security and privacy management, information ethics and strategy as well as by individuals about whom data are collected and stored by organizations such as universities. Smith et al (1996) discussed the construct of concern about improper access to data as follows:

"Who within an organization is allowed to access personal information in the files? This is a question not only of technological constraints (e.g., access control software) but also of organizational policy. It is often held that individuals should have a "need to know" before access to personal information is granted. However, the interpretation of which individuals have, and do not have, a "need to know" is often a cause of much controversy. PPSC (1977) and Linowes (1989) provide some attention to the topic--considering, for example, the inappropriate access to employees' healthcare records that are not controlled properly--and it is sometimes considered under the rubric of "security" in database literature (see, for example, Date, 1986). Of course, technological options now exist for controlling such access at file, record, or field level. But how those options are utilized and how policies associated with those uses are formed represent valueladen managerial judgments."

Students' concern about improper access to data $\left(\mathrm{X}_{2}\right)$ refers to students' fear or apprehension regarding adequacy of managerial practices and value-laden managerial judgments that drive practices and policies to protect customers' information privacy and security. Students' concern reflect the extent to which they believe that their privacy and security is being compromised or violated because of ignorance, incompetence, negligence, malice or criminal intent on the part of information managers and knowledge workers at universities.

\section{Research Questions $\left(R Q_{i}\right)$ and Hypotheses $\left(H_{i}\right)$}

The discussions presented this far can be summarized in the form of three research questions and the related hypotheses.

$\mathrm{RQ}_{1}$ : Do customers who report that they are concerned about an organization's practices related to management of error in data feel alienated towards that organization as a result of relevant organizational practices?

$\mathbf{H}_{1}$ : The higher students' concern about error in data $\left(\mathrm{X}_{1}\right)$, the higher their feeling of being alienated $(\mathrm{Y})$ by their university. It is expected that there is a positive correlation between $\mathrm{X}_{1}$ and $\mathrm{Y}$. $\left(B_{1} \mathrm{X}_{1}>0\right)$.

$\mathrm{RQ}_{2}$ : Do customers who report that they are concerned about how well organizations protect customers against improper access to personal data feel alienated by organizations as a result of relevant organizational practices?

$\mathbf{H}_{2}$ : The higher the level of concern about improper access to data $\left(\mathrm{X}_{2}\right)$, the higher the level of alienation (Y). It is expected that there is a positive correlation between $\mathrm{X}_{2}$ and $\mathrm{Y} .\left(B_{2} \mathrm{X}_{2}>0\right)$.

$\mathrm{RQ}_{3}$ : Does the feeling of alienation $(\mathrm{Y})$ resulting from concern about improper access to data $\left(X_{2}\right)$ vary according to customers' level of concern about error in data $\left(\mathrm{X}_{1}\right)$ ?

$\mathbf{H}_{3}$ : Given the same level of concern about improper access to data $\left(X_{2}\right)$, individuals with higher score on concern about error in data $\left(\mathrm{X}_{1}\right)$ will feel more alienated $(\mathrm{Y})$ than individuals with lower score on concern about error in data. Concern about error in data $\left(\mathrm{X}_{1}\right)$ positively influences (reinforces) the effect of concern about improper access to data $\left(\mathrm{X}_{1}\right)$ on customers' feeling of alienation $(\mathrm{Y})$. $\left(B_{3} \mathrm{X}_{1 *} \mathrm{X}_{2}>0\right)$.

\section{SAMPLE, DATA COLLECTION AND RESEARCH METHODS}

The sample consisted of 187 students from a large university in the U.S. There were no instances of missing data because the survey was set up online in a way that did not allow respondents to submit the survey without answering all the questions. Students got extra credit points for participating in the survey. Out of 220 students we solicited, 187 completed the survey. Because of this high response rate, non-response bias, if any existed, would not be high. Of the 187 students, 37 were 
graduate business students and 150 were undergraduate business students. Statistical tests indicated no significant differences between graduate and undergraduate students' scores on the variables under study. The percentage of male (52\%) and female (48\%) students were almost equal.

Seven-point Likert scales were used to measure the level of concerns students had about error in data, improper access to data and alienation. The items for measuring concern about data collection and use were taken from Smith et al (1996) and the items to measure alienation were from Allison (1978) and Singh (1990). The items in the questionnaire were adapted to the context of students' perception of data collection and use by universities. These modified items are presented in Appendix A.

\section{RESULTS}

$\mathrm{X}_{1}, \mathrm{X}_{2}$ and $\mathrm{Y}$ are average composite scores from multi-item scales used in the survey instrument presented in Appendix A. The item indicated with ${ }^{\circledR}$ was reverse-coded. The mean score on students' concern about improper access to data $\left(\mathrm{X}_{2}\right)$ is 5.95 compared against a mean score of 5.88 for concern about error in data $\left(\mathrm{X}_{1}\right)$. Students' concern about error in data (X1) was not found to be significantly higher than their concern about improper access to data (X2). The mean score on alienation was not an extreme value - it was 4.20 on a scale ranging from 1 to 7 where higher values indicated higher level of alienation [Table 2].

\begin{tabular}{|r|r|r|r|r|r|r|}
\hline \multicolumn{7}{|c|}{ Table 2: Average, Sample Standard deviation and Correlation Matrix } \\
\hline $\mathrm{n}=187$ & Average & Sample Std & $(\mathrm{X} 1)$ & $(\mathrm{X} 2)$ & $\left(\mathrm{X}{ }^{*} \mathrm{X} 2\right)$ & $(\mathrm{Y})$ \\
\hline Concern-Error (X1) & 5.88 & 0.66 & 1 & & & \\
\hline Concern-Access (X2) & 5.95 & 0.87 & 0.598 & 1 & & \\
\hline $\mathrm{X} 1^{*} \mathrm{X} 2$ & 35.35 & 7.70 & 0.856 & 0.919 & 1.000 & \\
\hline Alienation (Y) & 4.14 & 0.94 & 0.018 & 0.152 & 0.112 & 1 \\
\hline & & & & & & \\
\hline
\end{tabular}

Table 3 indicates that the multiple regression model in which $X_{1}, X_{2}$ and the interaction of $X_{1}$ and $X_{2}$ have been used to predict and explain students' feeling of alienation $(\mathrm{Y})$ is statistically significant ( $\mathrm{p}$-value $=0.074$ ) at alpha 0.10 but the interaction term is not (p-value .2917>.10) statistically significant. The individual coefficient terms in this model will not be interpreted because the two independent variables exhibit multicollinearity. Multicollinearity makes determining the contribution of each independent variable in explaining Y difficult because the effects of the independent variables $\mathrm{X}_{1}$ and $\mathrm{X}_{2}$ are mixed or shared by each other (Hair et al 1998, p.188) However, the interaction term $\left(\mathrm{B}_{3} \mathrm{X}_{1 *} \mathrm{X}_{2}\right)$ can be interpreted as statistically not significant ( $\mathrm{p}$-value $=0.2917$ ) and this indicates that the sample evidence is not adequate to support $\mathrm{H}_{3}$. The reason for testing $\mathrm{H}_{3}$ is to find out if students' alienation associated with their concern about error in data (X1) varies depending on the level of concern they have about improper access to data (X2).

\begin{tabular}{|c|c|c|c|c|c|}
\hline SUMMARY OUTPUT & \multicolumn{5}{|c|}{ Table 3: Full Regression Model with interaction term } \\
\hline \multicolumn{6}{|c|}{\begin{tabular}{|l|l} 
Regression Statistics & \\
\end{tabular}} \\
\hline Multiple R & \multicolumn{5}{|l|}{0.19244} \\
\hline R Square & \multicolumn{5}{|l|}{0.037033} \\
\hline Adjusted R Square & \multicolumn{5}{|l|}{0.021247} \\
\hline Standard Error & \multicolumn{5}{|l|}{0.928327} \\
\hline Observations & \multicolumn{5}{|l|}{187} \\
\hline \multicolumn{6}{|l|}{ ANOVA } \\
\hline & $d f$ & SS & $M S$ & $F$ & Significance F \\
\hline Regression & 3 & 6.06 & 2.02 & 2.346 & 0.0743445 \\
\hline Residual & 183 & 157.71 & 0.86 & & \\
\hline Total & 186 & 163.77 & & & \\
\hline \multicolumn{6}{|c|}{ Regression Model: $\mathrm{Y}=\mathrm{B} 0+\mathrm{B} 1^{*} \mathrm{X} 1+\mathrm{B} 2^{*} \mathrm{X} 2+\mathrm{B} 3^{*} \mathrm{X} 1^{*} \mathrm{X} 2$} \\
\hline & Coefficients & Standard Error & t Stat & P-value & \\
\hline Intercept & 6.6314 & 2.87 & 2.31 & 0.0218 & \\
\hline Concern-Error (X1) & -0.6953 & 0.52 & -1.33 & 0.1850 & \\
\hline Concern-Access (X2) & -0.3025 & 0.52 & -0.58 & 0.5606 & \\
\hline$\longdiv { X 1 ^ { * } X 2 }$ & 0.0961 & 0.09 & 1.06 & 0.2917 & \\
\hline
\end{tabular}


Hypotheses $\mathrm{H}_{1}$ and $\mathrm{H}_{2}$ regarding the main effects of $\mathrm{X}_{1}$ and $\mathrm{X}_{2}$ on $\mathrm{Y}$ were tested separately in two regression models which we present in Table 4. As indicated by the $\mathrm{p}$-values in Table $4, \mathrm{X}_{1}$ is not (p-value $0.8018>.10$ ) a statistically significant predictor of students' alienation $(\mathrm{Y})$ but $\mathrm{X}_{2}$ is ( $\mathrm{p}$-value $0.0381<.10$ ). Hypothesis $\mathrm{H}_{2}$ is supported by the sample evidence, but the sample evidence is not adequate to support hypothesis $\mathrm{H}_{1}$. One possible explanation is that students have not experienced anything negative with regard to error in data $\left(\mathrm{X}_{1}\right)$ but they may have experienced or been informed by the media or by social networks about problems regarding improper access to data $\left(\mathrm{X}_{2}\right)$.

\begin{tabular}{|l|l|r|r|}
\hline Table 4: Two Simple Regression Models & & \\
\hline Specified Model & Model Estimate & Model P-value & $\mathrm{n}$ \\
\hline $\mathrm{Y}=\mathbf{B o + B 1}{ }^{*} \mathbf{X} 1$ & $\mathrm{Y}=3.9845+0.02627^{*} \mathrm{X} 1$ & $\mathbf{0 . 8 0 1 8}$ & 187 \\
\hline $\mathrm{Y}=\mathbf{B o + B 1}^{*} \mathbf{X} \mathbf{2}$ & $\mathrm{Y}=3.16447+\mathbf{0 . 1 6 3 7 4}{ }^{*} \mathrm{X} 2$ & $\mathbf{0 . 0 3 8 1}$ & 187 \\
\hline
\end{tabular}

\section{DISCUSSION, IMPLICATIONS AND FUTURE RESEARCH}

The results indicate that students' concern about improper access to data is likely to strengthen their feeling of alienation toward their university. For a university's information policy makers, system designers and administrators, this finding can be a call for addressing students' concern about improper access to student records so as to minimize their level of alienation. Correlation between a dimension $\left(\mathrm{X}_{2}\right)$ of information privacy concerns and alienation $(\mathrm{Y})$ does not necessarily prove that privacy concerns cause alienation. However, since alienation can be a factor responsible for students' poor performance, their non-cooperation and withdrawal, revolts, protests or violence, the findings of this study are important for all parties related to universities. We have found empirical support that students' concern about improper access to data is most likely among the factors responsible for students' feeling of alienation. If alienation related to privacy concerns can be reduced, students may be more interested to cooperate with their university and cherish their identity as a member of the university community during their period of study and long after they graduate. At a more practical level, alienation can be associated with students' level of charitable giving to the university in the future and whether or not they speak favorably to prospective students, donors or other patrons. Even though the study has been done in the context of a university, its findings might, with caution, be generalized to other information-based organizations where customers or subjects of data collection are internalized members of the organizational community.

Researchers can build on this study to examine other sources of students' or customers' alienation by organizational information management policies, practices and systems. Examples of such other sources could be nationality, culture, ethnicity, religion, personality type, political beliefs and different privacy and security policies and practices that define organizational practices. Research can also be conducted to examine the effects of alienation on other constructs such as customers' willingness to give data, and their willingness to participate in different group activities sponsored by their organizations. Some qualitative interviews with students revealed that they were concerned because they were not adequately informed about who have access to data about them that have been collected and stored by universities. Students' concern about improper access $\left(\mathrm{X}_{2}\right)$ and the resulting alienation $(\mathrm{Y})$ could simply be the result of students' not knowing what kind of access control mechanisms are in place at a university. A university's information collectors, users, managers, system designers, policy makers, data managers, and database administrators can conduct qualitative interviews to identify with greater detail what specific aspects of information management practices, policies and activities related to management of access control raise students' concern about improper access so that they can take actions that can reduce their privacy concerns and associated feeling of alienation. This study can be a guide in that direction.

\section{REFERENCES}

1. Allison, Neil K.., "A Psychometric Development of a Test for Consumer Alienation from the Marketplace." Journal of Marketing Research (JMR), Nov78, Vol. 15 Issue 4, p565, 11p

2. Alvarez, Antonio G.; Welsh, James J.., “Adventure: A model of experiential learning." Social Work in Education Oct90, Vol. 13 Issue 1, p49, 9p

3. Barnard, C. I. (1938) The functions of the executive. Cambridge, M.A: Harvard University Press.

4. Bennett, C. J. Regulating Privacy: Data Protection and Public Policy in Europe and the United States, Cornell University Press, Ithaca, NY, 1992.

5. Berghel, Hal; "Caustic Cookies." Communications of the ACM, May2001, Vol. 44 Issue 5, p19, 4p

6. Borna, Shaheen; Avila, Stephen; "Genetic information: Consumers' right to privacy versus insurance companies' right to know..." Journal of Business Ethics, May99, Vol. 19 Issue 4, p355, 8p 
7. Brookes, Geoff., "From rebellion to class war". Times Educational Supplement, 3/29/2002 Issue 4474, p33, 1/2p;]

8. Cespedes, F. V. and Smith, H. J. "Database Marketing: New Rules for Policy and Practice," Sloan Management Review (34), Summer 1993, pp. 7-22.

9. Culnan, M. J. "'How Did They Get My Name?': An Exploratory Investigation of Consumer Attitudes Toward Secondary Information Use," MIS Quarterly (17:3), September 1993, pp. 341-363.

10. Culnan, Mary J.; Armstrong, Pamela K.., "Information privacy concerns, procedural fairness, and impersonal trust: An empirical investigation." Organization Science: A Journal of the Institute of Management Sciences, Jan/Feb99, Vol. 10 Issue 1, p104, 12p.

11. Date, C.J. An Introduction to Database Systems (4th ed.), Addison-Wesley Publishing Company, Reading, MA, 1986.

12. Dean, Dwight. "Alienation and Political Apathy," Social Forces, 38 (March 1960), 185-9.

13. --- --- “Alienation: Its Meaning and Measurement," American Sociological Review, 26 (October 1961), 753-8.

14. Donaldson, Lex (1995). American anti-management theories of organization: a critique of paradigm proliferation; Cambridge studies in management 25; Cambridge University Press, New York.

15. Drucker, P.F. (1988, January-February). "The coming of the new organization." Harvard Business Review, pp.48-53

16. Freeman, R. E. 1984. Strategic management: A stakeholder approach. Boston: Pitman Publishing.

17. Friedland, Stan., "Less Violence?" Change School Culture.; Education Digest, Sep99, Vol. 65 Issue 1, p6, 4p;

18. Garfinkel, Simson (2000). Database Nation. O’Reilly \& Associates, Inc.

19. Hafner, K.M.., "How Computer Associates climbed to No. 1" Business Week, 7/11/88 Issue 3060, p77, 2p

20. Hair, Joseph F. Jr. Anderson, Rolph E.Tatham, Ronald L and Black, William C. Multivariate Data Analysis (1998), fifth edition, Prentice Hall

21. Hancock, Bill; "Student Privacy A Congressional Concern." Computers \& Security, 2001, Vol. 20 Issue 2, p106

22. Hemphill, Thomas A. "DoubleClick and Consumer Online Privacy: An E-Commerce Lesson Learned." Business \& Society Review, Fall2000, Vol. 105 Issue 3, p361, 12p

23. HEW (U.S. Department of Health, Education, and Welfare). Records, Computers, and the Rights of Citizens: Report of the Secretary's Advisory Committee on Automated Personal Data Systems, U.S. Government Printing Office, Washington, D.C., 1973.

24. Kent, Stephen T. "Internet privacy enhanced mail. (cover story)". Communications of the ACM, Aug93, Vol. 36 Issue 8, $\mathrm{p} 48,13 \mathrm{p}$

25. Kling, R. "Value Conflicts and Social Choices in Electronic Funds Transfer Systems Developments," Communications of the ACM (21:8), August 1978, pp. 642-657.

26. Laudon, K.C. Dossier Society: Value Choices in the Design of National Information Systems, Columbia University Press, New York, 1986.

27. Linowes, D. F. Privacy in America: Is Your Private Life in the Public Eye? University of Illinois Press, Urbana, IL, 1989.

28. Lipton, David., "Now hear this...Customer complaints are not bad if viewed as business-building occasions." Nation's Restaurant News, 08/28/2000, Vol. 34 Issue 35, p30, 2p

29. Ma, Qingxiong; Pearson, John M. "An Exploratory Study of Information Security Objectives and Practices" Doctoral Dissertation, Southern Illinois University at Carbondale, IL, USA. (Supervisor: Pearson, John M.), 2004.

30. Mason, R. O. "Four Ethical Issues of the Information Age," MIS Quarterly (10:1), March 1986, pp. 4-12.

31. Mason, Richard O. Mason, Florence M. Culnan, Mary J. Ethics of Information Management. Sage series in business ethics (SSBE). Sage Publications, 1995.

32. Milberg,Sandra J.; Burke, Sandra J.., "Values, personal information privacy, and regulatory approaches." (cover story); Communications of the ACM, Dec95, Vol. 38 Issue 12, p65, 10p

33. _ .; Smith, H. Jeff; Burke, Sandra J.., "Information Privacy: Corporate Management and National Regulation."Organization Science: A Journal of the Institute of Management Sciences, Jan/Feb2000, Vol. 11 Issue 1, p35, 23p.

34. Miller, A. "Computers and Privacy," in Ethics and the Management of Computer Technology, W. M. Hoffman, and J. M. Moore (eds.), Oelgeschlager, Gunn, and Hain Publishers, Inc.,Cambridge, MA, 1982.

35. Mollick, Joseph S; Pearson, John M. "Effects of Two Information Privacy Concerns on Students' Feeling of Alienation" in Proceedings of the Americas Conference on Information Systems 2003: August 4- 6 : Tampa, Florida.

36. Mowshowitz, A. The Conquest of Will, Addison-Wesley, Reading, MA, 1976.

37. Nettler, g.A. "A Measure of Alienation," American Sociological Review, 22 (December 1957), 870-7.

38. Panichpathom, Supeecha. Doctoral dissertation: "An Examination of the Willingness to Engage in Web-Based Purchase: The Impact of an Individual Buyer's Trust of Sensitive Information Exchange," University of Texas at Arlington, December 2000. 
39. PPSC (Privacy Protection Study Commission). Personal Privacy in an Information Society: Report of the Privacy Protection Study Commission, U.S. Government Printing Office, Washington, D.C., 1977

40. Rackow, Sharon H.. "HOW THE USA PATRIOT ACT WILL PERMIT GOVERNMENTAL INFRINGEMENT UPON THE PRIVACY OF AMERICANS IN THE NAME OF 'INTELLIGENCE' INVESTIGATIONS." University of Pennsylvania Law Review, May2002, Vol. 150 Issue 5, p1651, 46p.

41. Rindfleisch, Thomas C. "Privacy, information technology, and health care." Communications of the ACM, Aug97,Vol. 40 Issue 8, p93, 8p

42. Rotenberg, Marc . "Communications privacy: Implications for network design." (cover story) Communications of the $A C M$, Aug93, Vol. 36 Issue 8, p61, 8p

43. Sethna, Beheruz; Barnes, Cynthia C. "E-Mail Communications in Colleges and Universities: Are They Private?" Journal of Education for Business, Jul/Aug99, Vol. 74 Issue 6, p347, 4p

44. Smith, H. J. Managing Privacy: Information Technology and Organizational America, University of North Carolina Press, Chapel Hill, NC, 1994.

45. Smith, H. Jeff; Milberg, Sandra J. "Information privacy: Measuring individuals' concerns about organizational practices." MIS Quarterly, Jun96, Vol. 20 Issue 2, p167, 30p

46. Singh, Jagdip (1988). "Consumer Complaint Intentions and Behaviors: Definitional and Taxonomical Issues," Journal of Marketing, 52 (January), 93-107.

47. _ (1990) “A typology of Consumer Dissatisfaction Response Styles," Journal of Retailing, 66 (Spring), 57-97.

48. _ and Robert E. Wilkes (1996), "When Consumers Complain: A Path Analysis of the Key Antecedents of Consumer Complaint Response Estimates," Journal of the Academy of Marketing Science, 24 (Fall), 350-65

49. Simon, H. A. (1976). Administrative behavior ( $3^{\text {rd }}$ ed.). New York: Mcmillan

50. Stone, E. F. and Stone, D. L. "Privacy in Organizations: Theoretical Issues, Research Findings, and Protection Mechanisms," in Research in Personnel and Human Resources Management (8), K. M. Rowland and G. R. Ferris (eds.), JAI Press, Greenwich, CT, 1990, pp. 349-411.

51. Stone, E. F., Gardner, D.G., Gueutal, H. G., and McClure, S. "A Field Experiment Comparing Information-Privacy Values, Beliefs, and Attitudes Across Several Types of Organizations," Journal of Applied Psychology (68:3), August 1983, pp. 459468.

52. Studdert, David M."Direct Contracts, Data Sharing and Employee Risk Selection: New Stakes for Patient Privacy in Tomorrow's Health Insurance Markets." American Journal of Law \& Medicine, 1999, Vol. 25 Issue 2/3, p233, 33p

53. Tanner, John C.., "Do I know you?" Telecom Asia, Apr98, Vol. 9 Issue 4, p6, 1/2p

54. Thompson, James D (1967). Organizations in action; social science bases of administrative theory; Published: New York, McGraw-Hill

55. Tolchinsky, P.D., McCuddy, M.K., Adams, J., Ganster, D.C., Woodman, R.W., and Fromkin, H.L. "Employee Perceptions of Invasion of Privacy: A Field Simulation Experiment," Journal of Applied Psychology (66:3), June 1981, pp. 308-313.

56. Vance, David (2000). Dissertation: On the Effect of Information Privacy Policy on Employment Opportunity Attractiveness (Supervisor: Arlyn Melcher), Southern Illinois University at Carbondale, IL 62901

57. Wang, Huaiqing; Lee, Matthew K.O.; et al. "Consumer privacy concerns about Internet marketing." Communications of the ACM, Mar98, Vol. 41 Issue 3, p63, 8p

58. Warren, Samuel D.; Brandeis, Louis D.., "Privacy, photography, and the press." Harvard Law Review, Feb98, Vol. 111 Issue 4, p1086, 18p (Originally published in 1890)

59. Westin, A. F. The Dimensions of Privacy: A National Opinion Research Survey of Attitudes Toward Privacy. January, 1979.

60. Westin, A. F. and Baker, M. A. Databanks in a Free Society, Quadrangle Books, New York, 1972. 


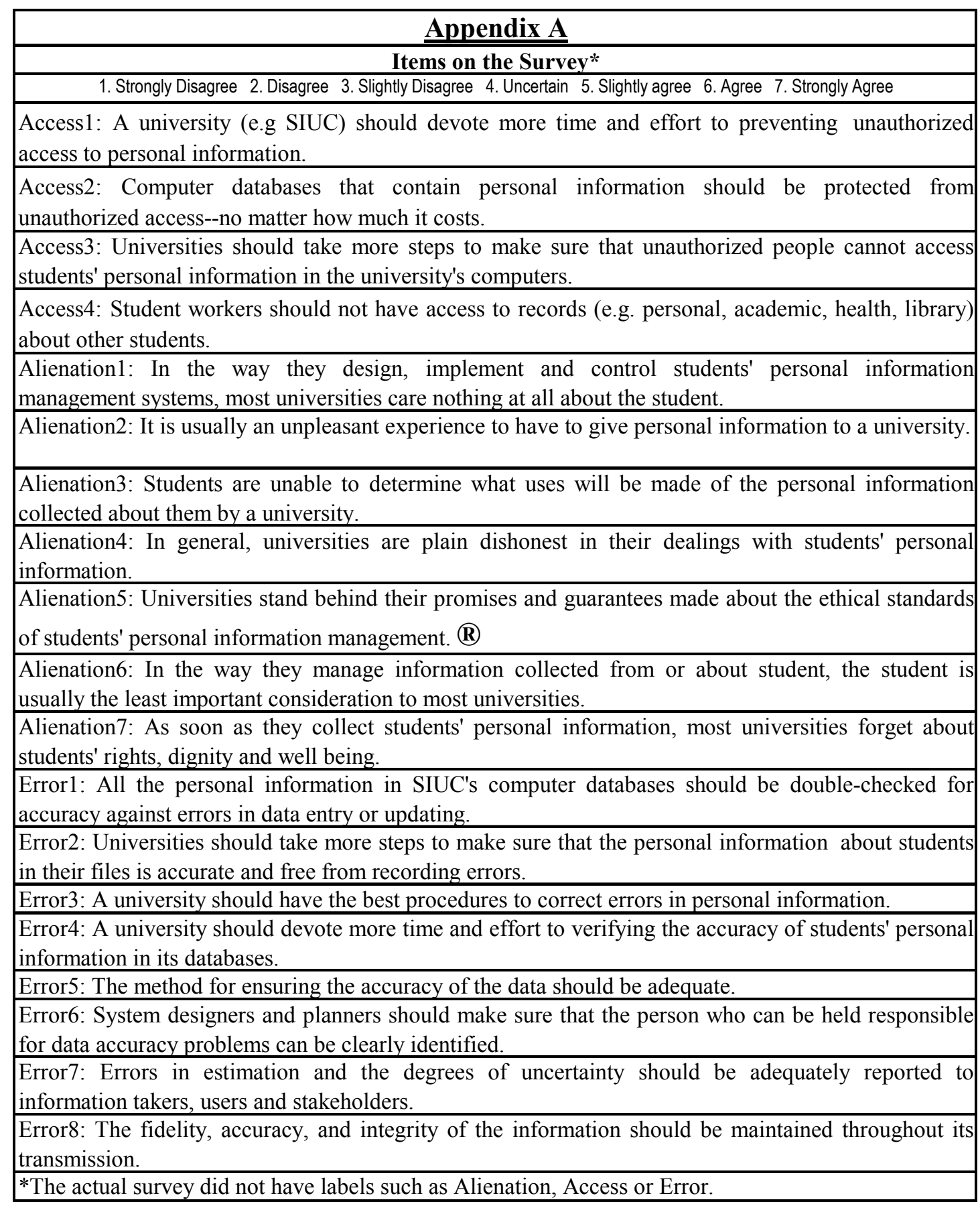

